\title{
Entrepreneurial Ecosystem Assessment in the Surgical Cotton Gauze and Bandage Cloth Cluster
}

\author{
Selvarani Mariappan, Muthulakshmi, Balakrishnan, Leena Jenefa
}

\begin{abstract}
Creating a sustainable entrepreneurial environment is vital for the success of cluster development. Surgical cotton and Bandage Cloth manufacturing is the traditional business for the people at Chatrapatti, Tamil Nadu, India. This cluster has more than 100 micro enterprises providing employment and contributing significantly to export. This research aims to assess the entrepreneurial ecosystem at Chatrapatti. A structured questionnaire is framed and collected from the 55 entrepreneurs at Chatrapatti and the result reveals that 92 percent of the entrepreneurs started sole proprietorship type of business without any business family background. 70 percent of them are degree or diploma holders, the majority of them are in the age category of 25 and above without prior industry experience from the same industry. The result reveals that capital, labor and raw material availability are the most influential factor to venture into the bandage cloth manufacturing business. Desire to make money, fear of unemployment and passion for self-employment are the highly motivating factors for starting the business. The entrepreneurs' skill assessment reveals that the entrepreneurs have good ability in fundraising and estimating the cash flows for the business. They have good negotiating and communication skill but lack the strategy for promoting the product using the social media and website for reaching the global market. Research result highlighted that the entrepreneurs are having good networking with supplier, and good ability in inventory management. Factor analysis revealed that the friends and family support, network, the success of friends in business are the highly motivating factors for starting the business. The entrepreneurs felt that the municipality compliance regarding the pollution control highly affects their business and need support from government to implement recycling technologies and supportive funding for implementing
\end{abstract} funding, factor analysis, motivational factor

\section{INTRODUCTION}

Government of India has formulated new policy measures and schemes to engage academia, industry, non-government organisation and investor to create the entrepreneurial culture, innovation, and development of

Revised Manuscript Received on December 16, 2019.

* Correspondence Author

Selvarani Mariappan*, Department of Business Administration, Kalasalingam Business School Kalasalingam Academy of Research and Education,Krishnan Koil, Tamil Nadu, India, selvarani05@gmail.com

Muthulakshmi Balakrishnan, MBA Student, Department of Business Administration, Kalasalingam Business School Kalasalingam Academy of Research and Education, Krishnan Koil, Tamil Nadu, India, muthubalumba@gmail.com

Leena Jenefa, DMI ST Eugene University, Lusaka, Zambia, jleenajenefa@gmail.com
Keywords: Entrepreneurial ecosystem, environment, skill and

enterprises in India. Developing and uplifting Micro Small and Medium Enterprises (MSME) is crucial for the sustainable development of India. The policy note 2018-19 of MSME department disclosed that the contribution of India's MSME is $45 \%$ to manufacturing and about $40 \%$ to exports and the National manufacturing Policy set the target of manufacturing sector contribution from $16 \%$ to $25 \%$ in GDP by 2022. Development of MSME's is possible with the creation and presence of good entrepreneurial Ecosystem. Table I reveals the exponential growth of MSME in Tamil Nadu in the sectors like garments, automobile components, and textile, etc. for the past ten years.

TABLE I Trend in the Growth of MSMEs in Tamil Nadu

\begin{tabular}{|c|c|c|c|}
\hline Year & $\begin{array}{c}\text { Number } \\
\text { of } \\
\text { Registere } \\
\text { d units }\end{array}$ & $\begin{array}{c}\text { Investmen } \\
t \\
\text { (Rs.crore) }\end{array}$ & $\begin{array}{l}\text { Employmen } \\
t \text { (Numbers) }\end{array}$ \\
\hline $2007-08$ & 27,209 & $2,547.14$ & $2,42,855$ \\
\hline 2008-09 & 32,049 & $3,557.89$ & $2,94,255$ \\
\hline $2009-10$ & 41,799 & $3,214.22$ & $1,51,743$ \\
\hline $2010-11$ & 57,902 & $5,872.37$ & $4,05,233$ \\
\hline 2011-12 & 70,758 & $7,429.59$ & $5,02,381$ \\
\hline $2012-13$ & 83,348 & $8,751.54$ & $5,83,436$ \\
\hline 2013-14 & $1,16,393$ & $18,939.87$ & $4,94,990$ \\
\hline $2014-15$ & $1,43,104$ & 24349.65 & $6,51,180$ \\
\hline $2015-16$ & $1,42,136$ & $34,411.90$ & $8,15,315$ \\
\hline $\begin{array}{l}\text { UAM * } \\
(\text { as on } 31.3 .2016)\end{array}$ & 41,656 & $6,218.69$ & $2,96,687$ \\
\hline $2016-17$ & $2,67,310$ & $36,221.78$ & $18,97,619$ \\
\hline $2017-18$ & $2,17,981$ & $25,373.12$ & $13,78,544$ \\
\hline
\end{tabular}

As per Industrial Profile of Virudhunagar district 2012-13 report, the Surgical Cotton Gauze and Bandage Cloth cluster in Chatrappatti has 100 Micro/Small companies, 5 Medium and Large companies, and producing Rs.110 Crores worth of Surgical Cotton Gauze and Bandage Cloth. It provides employment to 12,000 workers and contributes Rs.20crores to export.

Recently Indian government has announced medicinal bandages as technical textile and allotted harmonized system (HS) code. This will assist in identifying product during export and import and avail the subsidies and incentives. Moreover, the government of India probably is going to consider bringing mandatory standards for technical textiles items to boost the make in India initiative which will also develop quality in safety, health, and security.

Published By:

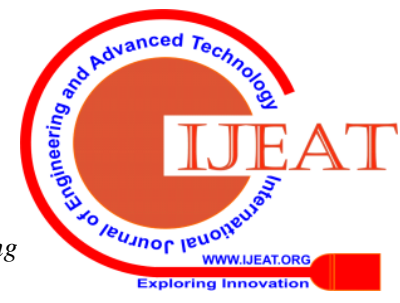


Implementation of technological changes and adoption of quality measures by micro small companies will boost the industry and its contribution to export. Assessing the present entrepreneurial ecosystem and identifying the key challenges faced by Surgical Bandage Cloth cluster in Chatrappatti and will help the government to formulate policy measures. This research work aims to assess the entrepreneurial ecosystem in Surgical Cotton Gauze and Bandage Cloth cluster at Chatrappatti.

\section{REVIEW OF LITERATURE}

Creating and sustaining entrepreneurial climate is a key challenge for the policymakers due to immense competition, the presence of internal and external factors and its influence on MSME is not predictable accurately. During the LPG period, studying the entrepreneurial ecosystem gains much popularity among academician, policymakers, and entrepreneurs. James Moore (1993), in his article, coined the term ecosystem and stated that the evolution of business happens with the interaction of firms with suppliers, financiers, and customers. Rosted (2012) stated that the presence of a dynamic ecosystem will create a better opportunity for new firms to grow and provide employment. The entrepreneurial ecosystem has several variants; it may be industry-specific, geographic/area specific or started from single industry and embed with multiple industries. The economic activities in a particular area formulate clustering and create conducive environment for a geographic specific industry.

Roxas, et.al. (2006), attempted to study the environment for entrepreneurship and formulate the local entrepreneurial climate conceptual frame work by identifying the formal and informal institutions at city level in their literature research. They identified the components of local Entrepreneurial Climate by combining five dimensions of formal institutions namely: social support system; structural support system; bureaucratic processes; incentives; and policies. The informal institutions include family support, informal network, propensity of risk, and acceptance in society.

Daniel Isenberg (2011) identified the novel strategy for economic development by creating entrepreneurship ecosystem which consists of numerous elements and grouped into six domains namely culture, policies, human capital, finance, markets, and supports. Entrepreneurial ecosystem is impacted by each domain and its influence will vary from time to time. He also found that the intensity of entrepreneurship in society is impacted by the level of education, legal frameworks, and regulatory measures and capital markets.

John D. Sullivan, Aleksandr Shkolnkov, (2004) identified through their research, simple business entry, proper information disclosure, property rights, finance, efficient labour law, encourage competition, simplified tax system, eliminating price control, establishing proper bankruptcy law, and inculcating technological, financial and administrative skills of entrepreneur are essential for developing entrepreneurial ecosystem and recommended to policy makers.

The entrepreneurial environment consists of several environment forces which are either facilitating or hindering the entrepreneurial activity development in the society. Gnyawali (1994) developed the entrepreneurial environment dimension which consists of socio, cultural, economic, and political factors. These factors impact the individual's ability and willingness to undertake business. Government policy motivates people to take a risk and start new enterprises. Simple rules and procedure encourage the entrepreneur to start a new venture (Fogel, 2001). Romanelli (1989) research found that the resources availability encourage entrepreneurship.

Yeboah (2014), research found that sociocultural environmental factors predominantly influence the development of the entrepreneurial environment. The level of education, family background, religion impacts the individual's entrepreneurial intention. Education level enhances the ability of the individuals and creates thrust for self-employment which in turn induces them to become an entrepreneur (Lucas, 1978; Kransniqi, 2009). Bwisa and Ndolo (2011), research shows that religion develops one's values, ethics and beliefs, and trust. It also influences the choice of entrepreneurial career of the individual especially women or group. Garba et al., (2013) research confirms the finding of Bwisa and Nodolo research. Family plays a crucial role in the choice of entrepreneurship. Geissler and Zanger, (2013) Wang et al., (2011) research reveals that the close association with the entrepreneur, their interaction and learning from them create a more chance to choose entrepreneurship career.

Krishna (2013) identified fear of unemployment, dissatisfaction with the current job, motivation to earn money and become self-reliant are the motivating factors for an individual to start the business. Davidson.et.al, (2006) research shows that the external factors and the choice of role model affect the new venture starting the process. The research work of Davisson (1991) revealed a high correlation between education and experience with an entrepreneur's ability to start and operate a business. Hence an intensive training program which imparts entrepreneurial skills is a key for opening a small business and its success (Ladzani \& Van Vuuren, 2002). Barba-sanchez and Atienza-sahuquillo (2012) research found that the making money does not attract the Spanish entrepreneur to start a new venture but creating self-employment and having business idea motivates them to venture into new business. This paper tries to assess the impact of sociocultural factors among the individual and groups entrepreneurial choice of Surgical Cotton Gauze and Bandage Cloth manufacturing business at Chatrappatti.

The Textile Report (2017) of Government of Gujarat projected that the global market of Meditech industry would reach US $\$ 20.23$ billion by 2022 and initiated schemes to capitalize the market opportunity by creating more startup in Meditech industry. In Tamil Nadu, Chatrapatti is a well-known cluster for Surgical Cotton Gauze and Bandage Cloth. Assessing the current entrepreneurial climate in this cluster will help the state government to devise the policy measures and build this cluster as highly competitive. Studying the entrepreneurial eco system will unfold the entrepreneurial intention, influencing factors and issues pertaining to this industry. 


\section{PROBLEM STATEMENT}

The Textile Report (2017) of Government of Gujarat projected that the global market of Meditech industry would reach US $\$ 20.23$ billion by 2022 and initiated schemes to capitalize the market opportunity by creating more startup in Meditech industry. In Tamil Nadu, Chatrapatti is a well-known cluster for Surgical Cotton Gauze and Bandage Cloth. Assessing the current entrepreneurial climate in this cluster will help the state government to devise the policy measures and build this cluster as highly competitive. Studying the entrepreneurial eco system will unfold the entrepreneurial intention, influencing factors and issues pertaining to this industry.

\section{A. Objective of the Study}

The objective of this research is to identify the influencing and motivating factors for starting a business, and assess the demographic, social and family factors, and skills of the entrepreneurs in Surgical Cotton Gauze and Bandage Cloth cluster at Chatrapatti, Tamil Nadu.

\section{B. Hypothesis}

Based on the objective the following hypothesis is formulated to assess the entrepreneurial ecosystem:

H1: There is no difference in the mean of the friends and family encouragement to entrepreneur to start business and the business family background.

$\mathrm{H} 2$ : There is no difference in the mean value of age and starting business to earn money

H3: There is no association between age and the choice of entrepreneurship to implement own business idea

\section{DATA AND METHODOLOGY}

The Structured questionnaire was prepared and data were collected from the entrepreneurs who are doing Surgical Cotton Gauze and Bandage Cloth manufacturing business at Chatrapatti, Tamil Nadu, India. The information of surgical cotton Gauze and bandage cloth manufacturing entrepreneur at Chatrapatti is collected from the Association. Interview with the entrepreneurs was conducted from January 2019 to March 2019. The researcher has chosen a convenient sampling covering 55samples. A preliminary study was conducted with the sample size of 20 and the final questionnaire is framed based on the result. The questionnaire consists of two segments with three constructs in each segment one which assesses the influencing and motivating factors for entrepreneurship and another assess the financial, marketing and operational skill of the entrepreneur. Five points Likert measurement scale was used to assess the factors and 38items were identified through a literature review. The reliability of the questionnaire is tested and the Cronbach Alpha value is at an acceptable level of 0.760 . (Table II)

TABLE II Reliability Statistics

\begin{tabular}{|c|c|}
\hline Cronbach's Alpha & No of Items \\
\hline 0.760 & 41 \\
\hline
\end{tabular}

To identify the major influencing and motivating factors to start Bandage cloth manufacturing business at Chatrapatti, factor analysis was used. Sampling adequacy was tested by Keiser-Meyer-Olkin measure. The appropriateness of factor analysis was tested by using Correlation Matrix and Bartlett's test of Sphericity. The most influencing factors of entrepreneurship motivation were identified by using Principal component analysis.

\section{ANALYSIS AND RESULTS}

\section{A. Demographic profile and Characteristics of the company}

The collected data through questionnaire from the entrepreneurs are summarized and the demographic profile of the entrepreneur and characteristics of the companies they promoted is given in TABLE III.

TABLE III Characteristics of a company and Demographic Profile

\begin{tabular}{|c|c|c|c|}
\hline Variables & Categories & Frequency & Percentage \\
\hline \multirow{2}{*}{ Type of Company } & Sole proprietorship & 51 & 92.7 \\
\hline & Partnership & 4 & 7.3 \\
\hline Gender & Male & 55 & 100 \\
\hline \multirow{4}{*}{ Investment } & $<$ Rs. 1000000 & 20 & 36 \\
\hline & Rs. $1000000-$ Rs. 1500000 & 22 & 40 \\
\hline & Rs.1700000- Rs. 2000000 & 10 & 18 \\
\hline & Rs.2500000- Rs.5000000 & 3 & 5 \\
\hline \multirow{9}{*}{ Turnover } & Rs.800000-Rs.1100000 & 2 & 4 \\
\hline & Rs.1200000- Rs. 1500000 & 11 & 20 \\
\hline & Rs. $1600000-$ Rs. 1800000 & 6 & 11 \\
\hline & Rs. $2000000-$ Rs. 2100000 & 8 & 15 \\
\hline & Rs. $2200000-$ Rs. 2500000 & 7 & 13 \\
\hline & Rs.2600000- Rs.3000000 & 5 & 9 \\
\hline & Rs.3200000- Rs.3500000 & 7 & 13 \\
\hline & Rs.4000000- Rs. 4500000 & 5 & 9 \\
\hline & Rs.5000000- Rs.6500000 & 4 & 7 \\
\hline \multirow{5}{*}{$\begin{array}{c}\text { Year of } \\
\text { establishment }\end{array}$} & $2014-2018$ & 14 & 25 \\
\hline & $2010-2013$ & 17 & 31 \\
\hline & 2005-2009 & 15 & 27 \\
\hline & $2000-2004$ & 8 & 15 \\
\hline & $<1999$ & 1 & 2 \\
\hline \multirow{6}{*}{ Education } & Illiterate & 1 & 1.8 \\
\hline & High School & 1 & 1.8 \\
\hline & Higher Secondary & 14 & 25.5 \\
\hline & Diploma & 16 & 29.1 \\
\hline & Graduate & 18 & 32.7 \\
\hline & Post graduate & 5 & 9.1 \\
\hline \multirow{3}{*}{$\begin{array}{l}\text { Age of the } \\
\text { entrepreneur }\end{array}$} & $<25$ years & 3 & 6 \\
\hline & 25 to 40 years & 20 & 36 \\
\hline & $>40$ years & 32 & 58 \\
\hline \multirow{4}{*}{$\begin{array}{c}\text { No of Employees } \\
\text { Employed }\end{array}$} & $7-10$ & 10 & 18.2 \\
\hline & $11-15$ & 26 & 47.3 \\
\hline & $16-20$ & 15 & 27.3 \\
\hline & $21-40$ & 4 & 7.3 \\
\hline \multirow{5}{*}{ Age of the firm } & 2 to 5 years & 14 & 25 \\
\hline & 6 to 9 years & 17 & 31 \\
\hline & 10 to 13 years & 13 & 24 \\
\hline & 14 to 17 years & 4 & 7 \\
\hline & 18 to 22 years & 7 & 13 \\
\hline Business Family & No & 37 & 67 \\
\hline Background & Yes & 18 & 33 \\
\hline Prior Industry & No & 36 & 65 \\
\hline Experience & Yes & 19 & 35 \\
\hline
\end{tabular}




\section{Entrepreneurial Ecosystem Assessment in the Surgical Cotton Gauze and Bandage Cloth Cluster}

This research found that companies in the sample are promoted by male entrepreneur $100 \%$, the majority of them are promoted in the form of a sole proprietorship (97\%). $99 \%$ of the entrepreneurs in the sample is running a micro enterprise which provides employment to a minimum of 7 and maximum of 40 employees per company. For the past decade, there is a tremendous growth of startup in this cluster promoted by graduate, diploma holders, and higher secondary completed individuals. This research also found that for the past five years there is no startup from the entrepreneurs with above 40 years of age.

Surprisingly the result given in Table IV revealed that $54.5 \%$ of the entrepreneurs in the sample ventured into Surgical Cotton manufacturing business without prior industry experience and business family background.

Table IV Cross tabulation

\begin{tabular}{|l|r|r|r|}
\hline \multirow{2}{*}{$\begin{array}{l}\text { Prior } \\
\text { Industry } \\
\text { Experience }\end{array}$} & \multicolumn{2}{|c|}{$\begin{array}{c}\text { Business family } \\
\text { background }\end{array}$} & \multirow{2}{*}{} \\
\cline { 2 - 4 } & \multicolumn{1}{|c|}{ Yes } & \multicolumn{1}{|c|}{ No } & \multicolumn{1}{c|}{ Total } \\
\hline \multirow{2}{*}{ Yes } & 12 & 7 & 19 \\
\cline { 2 - 4 } & $21.8 \%$ & $12.7 \%$ & $34.5 \%$ \\
\hline \multirow{2}{*}{ No } & 6 & 30 & 36 \\
\cline { 2 - 4 } & $10.9 \%$ & $54.5 \%$ & $65.5 \%$ \\
\hline Total & 18 & 37 & 55 \\
\cline { 2 - 4 } & $32.7 \%$ & $67.3 \%$ & $100.0 \%$ \\
\hline
\end{tabular}

\section{B. Influencing and Motivating Factors}

Literature review evidenced that there are different factors motivating the people to do business and it varies from country to country. This research confirmed the components of an entrepreneurial system stated by Isenberg (2011).

TABLE V Entrepreneurial Motivating Factors

\begin{tabular}{|c|c|c|c|}
\hline Influencing Factor & Mean & Rank & Result \\
\hline Capital Availability & 4.98 & 1 & More influence \\
\hline labor Availability & 4.82 & 3 & More influence \\
\hline Raw Material Availability & 4.96 & 2 & More influence \\
\hline Others Bad Experience & 3.25 & 6 & Neutral \\
\hline Own Bad Experience & 3.27 & 5 & Neutral \\
\hline Educational Background & 1.53 & 7 & $\begin{array}{ll}\text { Very } & \text { Less } \\
\text { influence } & \end{array}$ \\
\hline Government Policy/Rules & 4 & 4 & $\begin{array}{l}\text { Somewhat } \\
\text { influence }\end{array}$ \\
\hline Motivated Factor & Mean & Rank & Result \\
\hline Cheesed off with the present job & 4 & 4 & Motivated \\
\hline Fear of Unemployment & 4.45 & 3 & $\begin{array}{l}\text { Highly } \\
\text { motivated }\end{array}$ \\
\hline Desire to earn money & 4.87 & 1 & $\begin{array}{l}\text { Highly } \\
\text { motivated }\end{array}$ \\
\hline $\begin{array}{l}\text { Dissatisfaction with previous } \\
\text { job }\end{array}$ & 1.95 & 7 & Less motivated \\
\hline Implement own business idea & 3.71 & 6 & Motivated \\
\hline Independent living & 4.69 & 2 & $\begin{array}{l}\text { Highly } \\
\text { motivated }\end{array}$ \\
\hline Government support & 1.47 & 8 & $\begin{array}{ll}\text { Very } & \text { less } \\
\text { motivated } & \\
\end{array}$ \\
\hline To put own funds & 3.38 & 5 & Motivated \\
\hline Friends/Family Network & Mean & Rank & Result \\
\hline Friends/Family encouragement & 3.64 & 3 & Good Support \\
\hline
\end{tabular}

\begin{tabular}{|l|l|l|l|}
\hline $\begin{array}{l}\text { Friends/Family success } \\
\text { motivates to start business }\end{array}$ & 3.85 & 2 & Agree \\
\hline $\begin{array}{l}\text { Friends/Family are } \\
\text { entrepreneurs }\end{array}$ & 3.93 & 1 & Agree \\
\hline $\begin{array}{l}\text { Large network of } \\
\text { Friends/Family }\end{array}$ & 3.93 & 1 & Agree \\
\hline
\end{tabular}

The result shown in Table $\mathrm{V}$ highlighted that the respondents opinioned that the availability of capital, labor; raw Material and government policy are the most influencing factor for them to start the business of manufacturing surgical cotton. Contrary to the result outcome of Barba-sanchez and Atienza-sahuquillo (2012) research, our research has proven that the desire to make money, independent living, and fear of unemployment is the topmost motivating factors to start Surgical Cotton manufacturing business. The success of the friends, family members in business and network of business friends and family motivates them to start the business.

This research finding confirms the research outcome of Ozsoy, et.al (2001) who identified job security, and increasing the income is the motivating factor for Turkish entrepreneur. Benzing, et.al, (2009) found that making money is the highly motivating factor for African entrepreneurs.

The formulated hypotheses were tested by using ANOVA and Chi Square. The statistical test result shown in Table VI, confirms the fact of entrepreneurs without proper education, business family background and age factor ventured into this business.

TABLE VI ANOVA \& Chi Square test Result

\begin{tabular}{|l|r|r|l|}
\hline Null Hypothesis & $\boldsymbol{F}$ & \multicolumn{1}{|c|}{ Sig. } & Result \\
\hline $\begin{array}{l}\text { H1: There is no difference } \\
\text { in the mean of the friends } \\
\text { and family encouragement } \\
\text { in entrepreneurial career } \\
\text { choice and the business } \\
\text { family background. }\end{array}$ & 9.34 & .004 & $\begin{array}{l}\text { Reject null } \\
\text { hypothesis }\end{array}$ \\
\hline $\begin{array}{l}\text { H2: There is no difference } \\
\text { in the mean value of age } \\
\text { and starting business to } \\
\text { earn money }\end{array}$ & 1.80 & .176 & $\begin{array}{l}\text { Accept null } \\
\text { hypothesis }\end{array}$ \\
\hline $\begin{array}{l}\text { H3: There is no association } \\
\text { between age and the choice } \\
\text { of entrepreneurship to } \\
\text { implement own business } \\
\text { idea }\end{array}$ & $26.271 \mathrm{a}$ & $\begin{array}{r}\text { Asymp. } \\
\text { Sig. }\end{array}$ & $\begin{array}{l}\text { Reject null } \\
\text { hypothesis }\end{array}$ \\
\hline
\end{tabular}

\section{C.Entrepreneurial Skill Assessment}

The entrepreneurial skill set was assessed in the areas of finance, marketing and operational by having three constraints with 19items in the questionnaire. This identified the skills possessed by entrepreneurs, which help them to enter into business and lagging skill set for further development.

The entrepreneurial skill assessment result shown in Table VII shows that as for as managing money the respondents strongly agrees that they have strong skills in cash flow forecasting, negotiating with financier, and funding arrangement but lack in financial statement preparation and Payroll maintenance.
Published By:

Blue Eyes Intelligence Engineering \& Sciences Puhlication 
The respondents are strong in selling, marketing research and communicating with the customer but lack in formulating promotional strategy and using social and internet media for promoting business. Procurement of material is not the issue for the entrepreneurs in Chatrappati. They strongly agree that they have good inventory management skill and good experience in the purchase and dealing with the supplier. They felt that government regulation strongly affect their business.

Table VII Skill Assessment

\begin{tabular}{|l|l|c|l|}
\hline Managing Money & Mean & Rank & \multicolumn{1}{|c|}{ Result } \\
\hline Budget Skill & 3.95 & 5 & Agree \\
\hline Fund Raising Financial & 4.05 & 4 & Agree \\
\hline $\begin{array}{l}\text { Preparing } \\
\text { Statement }\end{array}$ & 3.45 & 8 & Undecided \\
\hline Cash flow Forecast & 4.53 & 1 & $\begin{array}{l}\text { Strongly } \\
\text { Agree }\end{array}$ \\
\hline Payroll Experience & 3.89 & 7 & Agree \\
\hline Tax Payment & 3.91 & 6 & Agree \\
\hline Arranging Credit & 4.35 & 2 & Agree \\
\hline Accounting & 4.31 & 3 & Agree \\
\hline Marketing research & Mean & Rank & Result \\
\hline Marketing research & 4.53 & 2 & $\begin{array}{l}\text { Strongly } \\
\text { Agree }\end{array}$ \\
\hline Pricing strategies & 3.78 & 5 & Agree \\
\hline Promotional strategy & 3.35 & 6 & Undecided \\
\hline Customer communication & 4.51 & 3 & $\begin{array}{l}\text { Strongly } \\
\text { Agree }\end{array}$ \\
\hline Sales experience & 4.55 & 1 & $\begin{array}{l}\text { Strongly } \\
\text { Agree }\end{array}$ \\
\hline Competitor analysis & 3.8 & 4 & Agree \\
\hline Using social media & 1.65 & 7 & $\begin{array}{l}\text { Strongly } \\
\text { Disagree }\end{array}$ \\
\hline Operational Experience & Mean & Rank & Result \\
\hline Purchasing experience & 4.58 & 3 & $\begin{array}{l}\text { Strongly } \\
\text { agree }\end{array}$ \\
\hline Inventory management & 4.67 & 2 & $\begin{array}{l}\text { Strongly } \\
\text { agree }\end{array}$ \\
\hline Experience with suppliers & 4.84 & 1 & $\begin{array}{l}\text { Strongly } \\
\text { agree }\end{array}$ \\
\hline Web Development & 1.35 & 4 & $\begin{array}{l}\text { Strongly } \\
\text { Disagree }\end{array}$ \\
\hline Factor & Mean & Rank & Result \\
\hline $\begin{array}{l}\text { bunicipality rules affecting } \\
\text { ars }\end{array}$ & 4.75 & 1 & $\begin{array}{l}\text { Strongly } \\
\text { agree }\end{array}$ \\
\hline
\end{tabular}

\section{D.Social and Cultural Factors}

Interview with the respondent revealed that community funding plays a major role in entrepreneurs to venture into the development of new companies in this cluster. The weaving community living in Chathrapatti, Tamil Nadu and their social integration fills the gap of lack of government and institutional funding in this sector. The trust of the people in this community is a great asset for flourishing and sustaining this industry in this area. New entrepreneurs get funds from their society community funding system for machinery purchase and starting a business without giving any collateral security for loan, and written document for their loan amount. This trust, cooperative set up prevail in this society creates a favorable environment for a new entrepreneur to venture into this business.

Finding the most influencing factors for entrepreneurship is the aim of this research. Factor analysis has chosen for finding this. Before doing the factor analysis, its appropriateness and sampling adequacy are tested by correlation matrix, KMO and Bartlett's Test of Sphericity. The result of Bartlett's Test of Sphericity and KMO measure are shown in Table VIIII revealed that the sampling is adequate and there is a mediocre correlation between the factors. The Bartlett's Test of Sphericity is significant and suggested the suitability of factor analysis.

Factor analysis is performed separately for influencing and motivational factor and skill set assessment. Table IX displays the four most influencing and motivational factors obtained through principal component factor analysis and the extracted 14items with high eigenvalues for motivational factors together explains $73 \%$ variance.

As shown in Table $\mathrm{X}$ factor analysis for Skill set lead to five factors and all the items have high eigenvalues and explains about $75 \%$ variance.

TABLE VIII KMO and Bartlett's Test Result

\begin{tabular}{|c|c|c|}
\hline \multicolumn{3}{|c|}{ Influencing and Motivating Factors } \\
\hline \multicolumn{3}{|c|}{ Correlation Matrix - 0.000000188} \\
\hline \multicolumn{2}{|c|}{ Kaiser-Meyer-Olkin Measure of Sampling Adequacy. } & 0.600 \\
\hline \multirow[t]{3}{*}{ Bartlett's Test of Sphericity } & Approx. Chi-Square & 730.346 \\
\hline & $\mathrm{df}$ & 153 \\
\hline & Sig. & 0.000 \\
\hline \multicolumn{3}{|c|}{ Skill Set } \\
\hline \multicolumn{3}{|c|}{ Correlation Matrix - 0.00000000526} \\
\hline \multicolumn{2}{|c|}{ Kaiser-Meyer-Olkin Measure of Sampling Adequacy. } & 0.731 \\
\hline \multirow[t]{3}{*}{ Bartlett's Test of Sphericity } & Approx. Chi-Square & 886.394 \\
\hline & $\mathrm{df}$ & 190 \\
\hline & Sig. & 0.000 \\
\hline
\end{tabular}

TABLE IX Principal Component Factor Analysis (Varimax

\begin{tabular}{|l|c|c|c|c|}
\multicolumn{1}{|c|}{$\begin{array}{c}\text { Influencing and } \\
\text { Motivating Factors }\end{array}$} & $\begin{array}{c}\text { Factor } \\
\mathbf{1}\end{array}$ & $\begin{array}{c}\text { Factor } \\
\mathbf{2}\end{array}$ & $\begin{array}{c}\text { Factor } \\
\mathbf{3}\end{array}$ & $\begin{array}{c}\text { Factor } \\
\mathbf{4}\end{array}$ \\
\hline Capital availability & & & & 0.83 \\
\hline Labour availability & 0.551 & & & 0.69 \\
\hline $\begin{array}{l}\text { Raw material } \\
\text { availability }\end{array}$ & & 0.84 & & \\
\hline Own bad experience & & & 0.746 & \\
\hline Education & & & 0.87 & \\
\hline Government support & & & 0.82 & \\
\hline $\begin{array}{l}\text { Fear of } \\
\text { Unemployment }\end{array}$ & -0.695 & & & \\
\hline Desire to earn money & & 0.89 & & \\
\hline
\end{tabular}

Published By: 


\begin{tabular}{|l|l|l|l|l|}
\hline Implement own & & -0.59 & & \\
\hline Independent living & & 0.80 & & \\
\hline $\begin{array}{l}\text { Friends/Family } \\
\text { encouragement }\end{array}$ & 0.867 & & & \\
\hline $\begin{array}{l}\text { Friends/Family } \\
\text { success motivates to } \\
\text { start business }\end{array}$ & 0.954 & & & \\
\hline $\begin{array}{l}\text { Friends/Family are } \\
\text { entrepreneurs }\end{array}$ & 0.947 & & & \\
\hline $\begin{array}{l}\text { Large network of } \\
\text { Friends/Family }\end{array}$ & 0.942 & & & \\
\hline
\end{tabular}

The result of factor analysis identified friends, family members' encouragement, their success; network and funding through social setup are the most influencing factor for starting business. It is evidenced that the family and the social environment is conducive for persons to do business.

TABLE X Principal Component Factor Analysis (Varimax Rotation)

\begin{tabular}{|l|l|l|l|l|l|}
\hline Skill Set & $\begin{array}{c}\text { Factor } \\
\mathbf{1}\end{array}$ & $\begin{array}{c}\text { Factor } \\
\mathbf{2}\end{array}$ & $\begin{array}{c}\text { Factor } \\
\mathbf{3}\end{array}$ & $\begin{array}{c}\text { Factor } \\
\mathbf{4}\end{array}$ & $\begin{array}{c}\text { Factor } \\
\mathbf{5}\end{array}$ \\
\hline Accounting & & & & & 0.821 \\
\hline $\begin{array}{l}\text { Web } \\
\text { Development }\end{array}$ & & & & 0.872 & \\
\hline Budget Skill & 0.819 & & & & \\
\hline Fund Raising & 0.833 & & & & \\
\hline $\begin{array}{l}\text { Preparing } \\
\text { Financial } \\
\text { Statement }\end{array}$ & 0.685 & & & & \\
\hline $\begin{array}{l}\text { Cash flow } \\
\text { Forecast }\end{array}$ & 0.875 & & & & \\
\hline $\begin{array}{l}\text { Payroll } \\
\text { Experience }\end{array}$ & 0.853 & & & & \\
\hline Tax Payment & 0.834 & & & & \\
\hline $\begin{array}{l}\text { Arranging } \\
\text { Credit }\end{array}$ & 0.929 & & & & \\
\hline $\begin{array}{l}\text { Marketing } \\
\text { research }\end{array}$ & 0.843 & & & & \\
\hline $\begin{array}{l}\text { Pricing } \\
\text { strategies }\end{array}$ & 0.751 & & & & \\
\hline $\begin{array}{l}\text { Promotional } \\
\text { strategy }\end{array}$ & & 0.563 & & & \\
\hline $\begin{array}{l}\text { Customer } \\
\text { communicatio } \\
\text { n }\end{array}$ & & 0.923 & & & \\
\hline $\begin{array}{l}\text { Sales } \\
\text { experience }\end{array}$ & & & & & \\
\hline $\begin{array}{l}\text { Competitor } \\
\text { analysis }\end{array}$ & & & & & \\
\hline $\begin{array}{l}\text { Using social } \\
\text { media }\end{array}$ & & & & & \\
\hline $\begin{array}{l}\text { Purchasing } \\
\text { experience }\end{array}$ & 0.635 & & & & \\
\hline $\begin{array}{l}\text { Inventory } \\
\text { management }\end{array}$ & 0.733 & & & & \\
\hline $\begin{array}{l}\text { Experience } \\
\text { with suppliers }\end{array}$ & 0.663 & 0.526 & & & \\
\hline
\end{tabular}

\section{RECOMMENDATION TO POLICYMAKERS}

This research reveals that the funding is not the issue for the entrepreneurs to start a business in this cluster, but they lack in technological advancement, formulating promotional strategy and using social media and internet for reaching a global market. Ministry of MSME and Tamil Nadu government promote this cluster by organizing MediTech Expo and sponsoring the entrepreneurs to participate in the international exhibition to reach the global market.

Skill development training can be given to the entrepreneurs regarding digital marketing for reaching the untapped market and reap the market potential. Government of Gujarat has already implemented the various incentive schemes for promoting this industry. An entrepreneur who establishes new plant for value addition will get 5\% interest subsidy on bank loans for five years and 7\% interest subsidy on new plant and machinery for five years and providing financial assistance to support environmental compliance like energy and water conservation.

Entrepreneurs in the sample felt that the government rules, especially pollution control, affect their business and permanent solution for this is not sort out so far. The researcher recommends the government to create a facility for recycling industry wastage and reduce pollution control. Government has to fund or subsidize the investment in pollution control system by the micro enterprises to ease adoption. If state government provides subsidies for water conservation and recycling this industry will flourish and the entrepreneur will concentrate on further development.

\section{CONCLUSION}

The research analysed the entrepreneurial eco system prevailing in Surgical Cotton Gauze and Bandage Cloth cluster at Chathrapati, Tamil Nadu, India. This research reveals the interesting findings that the entrepreneurs in this cluster are risk takers. Without business background, education and experience ventured into this business and more number of micro enterprises is started with their supplier knowledge, managerial skills, and good funding by community. The social and family setup highly motivates and supports the entrepreneurs. Independent living, money making are the highly motivating factor for perusing entrepreneurship. This research finding is contrary with the previous studies in the aspects of implementing innovative idea as the primary motive for starting the business. The researcher believes that due to lack of this innovation motive, innovation is not taking place in terms of promoting the product, process, functional areas of business. Industry, Academic, government department and association tie-up will uplift this cluster by indicating skill gap and knowledge gap.

\section{REFERENCES}

1. Altinay, L., and Wang, C. L., "The influence of an entrepreneur's socio-cultural characteristics on the entrepreneurial orientation of small firms", Journal of Small Business and Enterprise Development, vol18 (4), pp. 673-694, 2011.

2. Barba-Sanchez, V., and Atienza-Sahuquillo, C., "Entrepreneurial behavior: Impact of motivation factors on decision to create a new venture", InvestigacionesEuropeas de Dirección y Economía de la Empresa, vol 18(2), pp. 132-138, 2012.

3. Brief Industrial Profile of Virudhunagar district 2012-13, MSME Development Institute, Chennai, http://dcmsme.gov.in/dips/IPS\%20Virudhunagar\%202012.pdf

4. Bwisa, H. M., \& Ndolo, J. M.,(2011) "Culture as a factor in entrepreneurship development: A case study of the Kamba culture of Kenya", International Journal of Business Management, vol (1), pp 20-29, 2011

\section{Published By:}

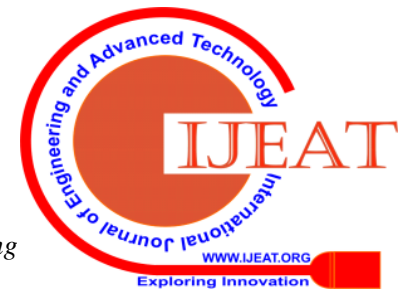


5. Daniel Isenberg, "Introducing the Entrepreneurship Ecosystem: Four Defining Characteristics," Forbes, May 25, 2011, http://www.forbes.com/sites/danisenberg/2011/05/25/introducing-the -entrepreneurship-ecosystem-four-defining-characteristics/.

6. Davidsson, Per and Hunter, Erik and Klofsten, Magnus, "Institutional Forces: The Invisible Hand That Shapes Venture Ideas?.", International Small Business Journal, vol 24(2), pp. 115-131, 2006.

7. Garba, A. S., Mansor, S. A., and Djafar, F. “An Exploratory Study on the Constraints for Entrepreneurial Activity: A Case of [8] Micro and Small Enterprises in Kano, Nigeria”. Journal of Applied Management and Entrepreneurship, vol18(4), pp. 79, 2013.

8. Geissler, M. and Zanger, C.,"Entrepreneurial role models and their impact on the entrepreneurial prefounding process", 2013.

9. Gnyawali, D. and Fogel, D. (1994), "Environments for entrepreneurship development: key dimensions and research implications". Entrepreneurship Theory and Practice, Volume: 18 issue: 4, page(s): 43-62

10. Gnyawali, D. R. and Fogel, D. S.," Environments for entrepreneurship development: Key dimensions and research implications", Entrepreneurship Theory \& Practice, summer, pp. 43-62, 1994.

11. HernanRoxas, Val Lindsay, Nicholas Ashill and AntongVictorio, "An Institutional View of Local Entrepreneurial Climate", Asia-Pacific Social Science Review, vol 7 NO. 1, pp. 27-44, 2006.

12. John D. Sullivan, Aleksandr Shkolnkov, "The Prosperity Papers \#1: Entrepreneurship", Economic Reform Issue Paper No. 0401, Oct 1, 2004,www.cipe.org/sites/default/files/publicationdocs/ IP0401.pdf

13. Krasniqi, B. A., "Personal, household and business environmental determinants of entrepreneurship", Journal of Small Business and Enterprise Development, vol16(1), pp. -166, 2009.

14. Krishna, M." Entrepreneurial motivation: A case study of small scale entrepreneurs in Mekelle, Ethopia”, Journal of Business Management \& Social Sciences Research, vol 2(1), pp. 1-6, 2013.

15. Ladzani, W. M. \& Van Vuuren, J. J., ’Entrepreneurship training for emerging SMEs in South Africa", Journal of Small Business Management 40(2), pp. 151-161, 2002.

16. Lucas Jr, R. E.,'On the size distribution of business firms", The Bell Journal of Economics, pp. 508-523, 1978.

17. Meditech Textile Application in Hygiene \& Surgical use, Textiles Government of Gujarat, 2017 Report

18. Moore, J.," Predators and Prey: A New Ecology of Competition", Harvard Business Review. May 1993

19. Ozsoy, O., Oksoy, D. and Kozan, K., "The Characteristics of Turkish Entrepreneurs and Their Enterprises", Long Island, NY: College of Business,Alfred University, 2001

20. Romanelli, E., "Organization birth and population variety: a community perspective on origins", In Research in Organizational Behavior, (eds), L. L. Cummings and B. M. Staw, vol 11, pp. 211-46, 1989. Greenwich, CT: JAI.

21. Rosted, J.,'Understanding Business Ecosystems", FORA Group, 2012

22. Yeboah, M. A.,"Analysis of entrepreneurship: How does culture influence risk-taking in SMEs in the Sekondi-Takoradi metropolis, Ghana?" American International Journal of Contemporary Research, vol 4(2), pp. 131-140, 2014.

\section{AUTHORS PROFILE}

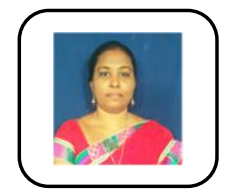

Selvarani Mariappan is currently working in Kalasalingam Business School, Kalasalingam Academy of Research and Education (Kalasalingam deemed to be University). She completed MBA from Mepco Schlenk Engineering College, India and ICWA Inter. She obtained her Doctorate from Kalasalingam University and is a researcher and teacher in the area of finance for more than 16 years. She expertise in stock market behavioral research and underwent FDP program on Econometrics in IIM, Kozhikode and published more research papers in a SCOPUS indexed journal and reviewer of finance journals. She contributed her research work as chapters in books. She writes extensively and presented papers in International and National Conference organised by IIT, IIM's and publishes scholarly works and case study. She got trained by
Infosys on Global Business Foundation Skill and NIT on Analytics. She conducted FDP, Workshop and gave guest lecture to Students, employees and research Scholars. She acted as a BOS member for SFR College, Sivakasi. She got awards for her competency in teaching for two times and faculty advisory ship from IQAC, KARE.

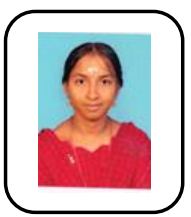

Muthulakshmi Balakrishnan completed B.Sc (CS) from A.K.D.Dharma Raja Women's College, Rajapalayam, Tamil Nadu and MBA from Kalasalingam Academy of Research and education. She is specialized in Finance and doing research in the field of entrepreneurship.

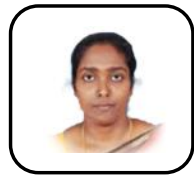

Leena Jenefa having 18 years' of experience in the teaching field. She received Ph.D. in Management from Manonmanium Sundaranar University, M.Phil Degree from Alagappa University, MBA from Madurai Kamaraj University and Bachelor of Commerce degree from Manonmanium Sundaranar University. Prior to joining DMI St Eugene University, She worked as a faculty member in Linton University affiliated to University of East London, Malaysia, The American College-Madurai, India, Francis Xavier Engineering College-Tirunelveli, India , Tecnia Institute of Advanced studies -Delhi, Lady Doak College, Madurai, India. She presented 37 research papers at international leve conferences and published 56 research articles in a reputed International journal with Impact factor and also been the Editor for 6 International Journal with ISSN . She acted as conference review committee member for INFOMS in Bangkok and in Dubai. She received Best Teacher Award for academics in the year 2008 from Tecnia Institute, Delhi. Best Outstanding Teacher Award from Venus International India, and Best Leadership award from IARDO India, She is the recipient of Best Editorial Board member award and Young Researcher award from Eureka Publication, 